\title{
The Effects of Corporate Financing Decisions on Firm Value in Bursa Malaysia
}

\author{
Chaleeda $^{1}$, Md. Aminul Islam ${ }^{1}$, Tunku Salha Tunku Ahmad ${ }^{1} \&$ Anas Najeeb Mosa Ghazalat ${ }^{2}$ \\ ${ }^{1}$ School of Business Innovation and Technopreneurship, Universiti Malaysia Perlis, Malaysia \\ ${ }^{2}$ School of Business Aministration, Arab Open University, Jordan \\ Correspondence: Chaleeda, School of Business Innovation and Technopreneurship, Universiti Malaysia Perlis, \\ Malaysia. Tel: 601-0226-6706. E-mail: chaleeda.s@gmail.com
}

Received: December 13, 2018

Accepted: February 26, 2019

Online Published: February 28, 2019

doi:10.5539/ijef.v11n3p127

URL: https://doi.org/10.5539/ijef.v11n3p127

\begin{abstract}
The primary objective of shareholders and financial managers is generally stated to be the maximization of shareholders' wealth by increasing the firm value. This research was undertaken to investigate the effect of corporate financing decisions on firm value. The research has been carried out using the panel data procedure for a sample of 256 firms from 9 sectors listed on Bursa Malaysia during the period 2000-2015. The study uses Tobin's Q representing firm value for the dependent variable. The corporate financing was measured by leverage (short-term debt to total assets, long-term debt to total assets, total debt to total assets and total debt to total equity) and debt maturity (long-term debt to total debt). Short-term debt to total assets and long-term debt to total assets has a positive significant relationship to firm value. This finding is consistent with the view that leverage and dividends mitigate agency costs of free cash flow problems, therefore, increasing firm value. Total debt to total assets affects firm value negatively. This proves that although there are benefits of debts, there is also the cost of debts. The cost of debt financing arises from the increase in the probability of bankruptcy. Firm value does not depend on the length of debt maturity.
\end{abstract}

Keywords: firm value, corporate financing decisions, leverage and debt maturity

\section{Introduction}

The primary objective of shareholders and financial managers is generally stated to be the maximization of shareholders' wealth. There are three forms of financial decisions which will influence the firm value which are investment decisions, financing decisions, and dividend decisions. Financing decisions are indeed one of the most complex areas of financial decision making due to their interrelationships with other financial decision variables (Nimalathasan \& Brabete, 2010). The problem of the study lies in the lack of clarity regarding the impact of capital structure on the value of the company, whereby managers need to choose a suitable financing structure for the company that contributes to maximizing its value, and thus maximizing the wealth of the owners of the company (Ramadan \& Ramadan, 2015). Limited research had been explicitly undertaken on the relationship between capital structure and firm value in Malaysia. Salim and Yadav (2012)'s study which involved examining the capital structure and firm performance, added that Tobin's Q is one of the performance indicators. While the literature reviewing the firm value implications of capital structure choices is extensive in developed markets (e.g., the USA and Europe), little is empirically known about such implications in transition or emerging economies such as Malaysia. In emerging countries, as Eldomiaty (2008) argued, the capital market is incomplete and less efficient and suffers from a greater level of information asymmetry more than capital markets in developed countries. This environment of the market may cause financing decisions to be incomplete and subject to a considerable degree of irregularity. Not only less research has been carried out on the impact of the capital structure on firm value, but the research that has been performed only considers leverage as the capital structure variable. Following Abor and Bokpin (2010) and Ardestani, Rasid, Basiruddin, and Mehri (2013), this research will add another variable to measure financing decisions which is debt maturity. Previous studies looking into the debt maturity structure of developing economies like Malaysia were also inadequate (Khaw and Lee, 2016). Although there is research undertaken on the determinants of debt maturity, limited effort has been made to explain the actual impact of debt maturity on firm value (Jiraporn \& Tong, 2008). Therefore, it is necessary to examine the impact of corporate financing decisions on firm value in Malaysia. 


\section{Literature Review}

Corporate financing decisions deal with the amount of capital that is required for a firm to operate and the best mix of capital structure for the firm (Pike \& Neale, 2009). To maximize the firm value, all the rational firms will pursue the lowest cost of capital and the optimal capital structure. Firms that have a pertinent blend of debt and equity will benefit the firm in the long run. The build-up of an optimal debt-equity mixture will reduce the cost of capital, and increase the net economic returns and consequently raise the firm's value (Awan, Bhatti, Ali, \& Qureshi, 2010).

Companies fund their investment projects using internal and external funds. Internal financing is whereby companies use non-cash expenses and retained earnings, and external financing refers to the proceeds from new equity and debt issuance. In a capital market world, internal and external funds are not perfect substitutes, and thus dividends, financing, and investment decisions are related (Simmons-Süer, 2016). Moreover, firms prefer to use internal funds to finance additional investments rather than issuing new securities because when there are capital market imperfections, internal funds are cheaper sources of financing. Correspondingly, with the limited amount of internal funds, there is a trade-off between dividends and investments (Dhrymes \& Kurz, 1967; Fama, 1974). In fact, Malaysian small firms rely on internal funds more as compared to external funds to finance their operations due to the higher cost of external financing for small firms compared to large firms (Karim \& Azman-Saini, 2013).

Following Ardestani et al. (2013), this study will explore two dimensions of capital structure which are financial leverage and debt maturity in discussing corporate financing decisions.

\subsection{Leverage}

Some past research has found that leverage has no impact on firm value. Jiraporn and Liu (2008) agree that if the leverage is too high, there is no significant adverse effect on firm value. Elkelish and Marshall (2012) conducted similar research in the United Arab Emirates (UAE) for food firms during 1996-2000 and deduces that debt to equity ratio does not affect firm value. A similar view is highlighted by Kodongo, Mokoaleli-Mokoteli, and Maina (2015) in their study on listed firms in Kenya. The study demonstrates that leverage does not affect firm value, which is measured by Tobin's Q. This shows evidence that the UAE and Kenya business environment agrees to the proposition of the MM theory. The reason being is that there are no debt tax shield benefits, the minimal value of perceived agency costs and bankruptcy in the market (Elkelish \& Marshall, 2012).

The second point of view is in line with the trade-off theory by Myers (1977) and Stulz (1990) inferred that debt might affect firm value positively or negatively because debt functions as a tool to manage agency costs of managerial discretion (underinvestment and overinvestment). For underinvestment, firms with a high debt level could forego profitable investment projects. Whereby the overinvestment of highly leveraged firms could lead managers to reject unprofitable projects that may increase the manager's liability. Debt financing is known to be a mechanism for managers to increase the shareholders' value and not make money for themselves (Chen, 2004). However, managers in profitable firms that utilize equity financing even with free cash flow available will not be committed to debt-repayment, and this could potentially decrease the shareholders' value (Tang \& Jang, 2007).

Leverage can provide tax benefits of debts, hence improving firm value (Tahir \& Razali, 2011; Zou, 2010). When managers are considering the firm's financing decisions, tax is one of the main elements to be considered. If firms choose debt financing, there will be a debt tax shield, which is the tax relief available on interest payments. However, if firms choose equity financing (using the shareholders' funds), then dividends will be distributed on the equity from the profit after tax, which will, in turn, give rise to a liability for personal income tax. According to the theory of debt tax shield, for two firms with an identical business size and expected future operation income, the firm with the lower-leveled capital structure usually has a lower market value compared to the firm with a higher leverage level and the difference in their market values comprise of the debt tax shield (Wang, 2015). Twairesh (2014) examined the relationship of capital structure decisions with the performance of firms listed on the Saudi Arabia Stock Exchange (TADAWUL) between 2004 and 2012 inferring that leverage has a strong significant impact on performance. Both Javeed, Hassan, and Azeem (2014) and Asif and Aziz (2016) studied firms listed on the Karachi Stock Exchange agree that capital structure has a significant positive relationship with firm value.

On the opposing view, debt financing may destroy value because of the bankruptcy costs that accompany it. In fact, firms with high leverage in capital structures raise the firms' risk of insolvency. Furthermore, firms with a higher possibility of bankruptcy would be required to pay higher debt interests and should comply with more constraints in debt covenants. The stricter requirements may consequently increase the firm's bankruptcy costs and the probability of bankruptcy. This is in line with a survey carried out on Malaysian CFOs by Nor, Ibrahim, 
Haron, Ibrahim, and Alias (2012) which revealed that Malaysian managers viewed internal funds as the most important source of financing to finance projects. Moreover, Malaysian managers believe that the potential costs of debt financing are much higher than the benefits. Leverage causes firm value discounts, whereas cash balances are valued positively by investors, but only up to a certain level (Loncan \& Caldeira, 2014). Vo and Ellis (2016) found that only low leveraged firms are likely to create shareholder value. They investigated the relationship between capital structure and value of shareholders in Vietnam and discovered that the cost of debt financing is more than the benefits received, suggesting that leverage had adverse effects to the value of the Vietnamese firms.

\subsection{Debt Maturity}

In a Modigliani-Miller world of frictionless capital markets, which is agreed by Stiglitz (1974), the relationship of debt maturity and firm value is irrelevant as firms can always refinance and recontract their way around the potential effects of a balloon debt payment. However, debt maturity choice is another aspect of capital structure which is proven to impact firm value. This is because the wrong choice of debt maturity might expose firms to interest rate fluctuations and potential rollover difficulties and consequently, make it difficult for firms to pursue valuable growth opportunities.

From one perspective, shorter maturity debt may enhance firm value as shorter maturity debt is beneficial because it alleviates the underinvestment and asset substitution problems (Myers, 1977). Also, Berlin (2006) highlighted that when firms have too much long-term debt, managers may forgo profitable investments. Jiraporn and Tong (2008) conducted comprehensive research, which encompasses over 100,000 observations across more than 14,000 firms over 32 years, between 1973 and 2004. They stated that firms that adopt a higher proportion of short-term debt experience an increase in firm value, consistent with the prediction of agency theory and the free cash flow hypothesis. This situation is especially true for firms in industries with lower agency conflicts (such as regulated utilities). Again, indicating the lower reliance on short-term debt as a disciplining tool in the presence of lower information asymmetries. The capital structure of Chinese firms also uses significantly more short-term debt, which is in sharp contrast to the debt policy in developed countries where long-term is more representative (Chen, Jiang, \& Lin, 2014).

On the other hand, longer maturity debt is also an advantage as long-term fixed-rate debt protects the borrower against fluctuations in interest rates. Also, the transaction costs of rolling over short-term debt may incur more costs as compared to one-time transaction costs of long-term debt. However, the idea that long-term debt is commonly used in developed countries as a consequence of their higher levels of credit monitoring and investor protection is rejected, and perhaps explains why they were perhaps more affected by the recent financial crises (Alves \& Francisco, 2015).

Although there are many studies on debt maturity, the focus has been on the determinants of debt maturity, and only a few research studies have examined its direct effect on firm value (Antoniou, Guney, \& Paudyal, 2006; Berlin, 2006; Terra, 2009). Therefore, this research will provide a significant and valuable contribution to the literature.

\section{Research Methodology}

\subsection{Sampling Design}

This study will adopt a quantitative research method by using secondary financial data extracted from the DataStream by Thomson Reuters. Companies from all sectors on the Main Board (2000-2008) and Main Market (2009-2015) of Bursa Malaysia, having complete data from 2000 to 2015 will be considered, except for the finance and utility companies due to the different regulations and face strict capital structure requirements. They must also have complete financial/accounting information, with no interruptions, during the study period. In addition, its shares have been subject to trading and transactions in Bursa Malaysia for 15 years (the study period; 2000-2015) and the trading and transactions in the shares of the company have not been disrupted in the time periods close to the dates of release of financial statements. Companies must not merge with other(s) or closed or delisted during the study period. According to these criteria, we examined 256 firms with 4,096 firm-year observations.

\subsection{Research Hypothesis}

The research will view corporate financing decisions from two dimensions; leverage and debt maturity. Although the previous research studies on leverage and firm value are mixed, this study hypothesises that leverage positively impacts firm value, especially in the case of Malaysia. Leverage can provide tax benefits of debts, hence improving firm value (Tahir \& Razali, 2011; Zou, 2010). Free cash flow may increase the strength of 
positive influence of leverage on value of the firm because through committing to the interest payment and avoid overinvestment, leverage is effective to reduce the agency problem of free cash flow (Cheng \& Tzeng, 2011). This positive effect of leverage on firm value will then be reflected in the stock price increase. Tahir and Razali (2011) proved the positive relationship right in their study of Malaysian public listed companies. The reason was because through leverage, firms are able to source the investment opportunities in their business without raising its equity. Hence, when the investment is profitable, shareholder's value will then be increased. Salim and Yadav (2012) also discovered a positive relationship between Tobin's Q and capital structure when conducting a study in Malaysia. The positive debt-value relationship is possible for Malaysian firms because they are not heavily dependent on debt, quoting an average debt of only $23 \%$ (Rashid, Nor, \& Ibrahim, 2013). Moreover, Rashid et al. (2013) further added that debt is an external fund, thus a higher use of debt will increase external monitoring. As a consequence of taking leverage, managers are subjected to more external monitoring by rating agencies, investors, and underwriters at issuance, creating the side benefit of leverage which is alleviating the agency costs of managerial discretion, thus will contribute positively towards the corporate value. Indeed, as added by Hermuningsih (2013), who conducted her study In Indonesia, the additional leverage sends a positive signal for investors and also improves firm value. The study also agrees that liability can help firms to control using available cash flow freely and excessively inside the firm by management. Therefore, this research hypothesises that leverage positively and significantly affects the value of the firm.

H1: There is a positive and significant relationship between leverage and firm value of Malaysian companies listed on Bursa Malaysia.

This study adds debt maturity as another corporate financing component. This is because this research believes that debt maturity can also affect firm value. In fact, shorter debt maturity can alleviate the agency costs of debt by resolving the asset substitution and underinvestment problems (Myers, 1977). Short-term debt is also a form of external financing and requires frequent renewal. Indirectly, it will increase external monitoring and thus will contribute positively toward corporate value. Jiraporn and Tong (2008) discovered that firms utilizing more short-term debt has higher firm value, and the relationship is stronger for firms with higher agency problems. Hence, this study proposes that the association between debt maturity and firm value is significantly negative.

H2: There is a negative and significant relationship between debt maturity and firm value of Malaysian companies listed on Bursa Malaysia.

\subsection{Research Variables}

Most research studying on correlation involving capital structure will proxy using the three ratios of short-term debt to total assets (STDA), the ratio of long-term debt to total asset (LTDA) and total debt to total asset (TDA) (Abor, 2005; Ebaid, 2009; Handoo \& Sharma, 2014). As cited in Ahmad and Aris (2015), Bevan and Danbolt (2002) and Sheikh and Wang (2013), they argued that a more precise view is obtained when these three proxies are used.

Following the research of Malik, Awais, and Qaisar (2016), Tan and Hamid (2016), Vătavu (2015) and Zeitun and Tian (2007), this study will further extend the research by adding another proxy which is total debt to total equity (TDTE) to represent leverage. Debt to equity ratio measures the firm's proportion that is financed by its debt holders as compared to its equity holders which are the owners (Ying, Annie, Jia, \& Ngar, 2012). Firms with more debt will have a very high debt to equity ratio, whereas firms with less debt will have a low debt to equity ratio. This implies that, ceteris paribus, firms with lower debt to equity ratios are more preferable instead of firms with higher ratios.

Next, debt maturity in this study will be calculated by the ratio of book value of long-term debt to total debt (LTDTD), where long-term debt is any debt maturing in more than one year (Dang, 2011; Fan, Titman, \& Twite, 2012; Orman \& Köksal, 2017). In summary, the study will apply four proxies to measure capital structure, namely; the ratio of short-term debt to total assets (STDA), long-term debt to total asset (LTDA), total debt to total asset (TDA) and total debt to total equity (TDTE) and one proxy to measure debt maturity which is long-term debt to total debt (LTDTD).

STDA $=($ Short term debt $) /$ (Total assets)

LTDA $=($ Long term debt $) /$ (Total assets)

TDA $=($ Total debt $) /($ Total assets $)$

TDTE $=($ Total debt $) /($ Total equity $)$

LTDTD $=($ Long term debt $) /$ (Total assets) 
This study uses profitability, asset tangibility, liquidity, firm age, firm risk and ownership structure as the control variables. Hence, this research will use the following model.

$$
\begin{gathered}
Q_{i t}=\beta_{0}++\beta_{1} \mathrm{STDA}_{i t}+\beta_{2} \mathrm{LTDA}_{i t}+\beta_{3} \mathrm{TDA}_{i t}+\beta_{4} \mathrm{TDTE}_{i t}+\beta_{5} \mathrm{LTDTD}_{i t}+\beta_{6} \mathrm{TANG}_{i t}+\beta_{7} \mathrm{LIQ}_{i t}+\beta_{8} \mathrm{SIZE}_{i t} \\
+\beta_{9} \mathrm{AGE}_{i t}+\beta_{10} \mathrm{RISK}_{i t}+\varepsilon_{i t}
\end{gathered}
$$

\section{Findings}

The panel data method is employed to investigate the influence of the independent variables on the dependent variable using the STATA statistical software, version 14, as it is appropriate for running and analysing panel data regression. The panel data analysis, which is a combination of both cross-section and time series data, has been used by many recent researchers (Ayturk, Gurbuz, \& Yanik, 2016; Dawar, 2014; Fosu, 2013; Karim, 2012; Rahim, Yaacob, Alias, \& Nor, 2010).

Table 1. Descriptive statistics of variables

\begin{tabular}{ccccccc}
\hline Stats & TOBINQ & STDA & LTDA & TDA & TDTE & LTDTD \\
\hline Mean & 4.239951 & 3.429088 & .092167 & .2395993 & .4908019 & .3915662 \\
P50 & .9070441 & .2549097 & .0412704 & .1947913 & .2962075 & .3411405 \\
Sd & 194.2234 & 197.805 & .1246189 & .5191544 & 4.467609 & .3202646 \\
Max & 14318 & 14318 & 1.495706 & 23.21788 & 208.4773 & 1 \\
Min & .0606974 & 0 & 0 & 0 & -178.3023 & 0 \\
\hline
\end{tabular}

Table 1 illustrates the descriptive statistics of the variables. The mean values of STDA, LTDA, and TDA are $29.25 \%, 9.09 \%$, and $21.98 \%$ respectively. This proves that firms rely more on STDA to finance their assets as compared to LTDA. The results are consistent with results found in earlier studies. This relatively low debt usage could be partly due to the small debt capital market in Malaysia. The mean of TDTE explains that firms take $49.08 \%$ from external parties to finance their assets. The mean value of LTDTD is 0.3915 implying that $39.15 \%$ of total debt belongs to the long-term debt category.

To analyze the impact of the corporate financing variables on firm value, this study used the random effect regression models following the results of the Hausman test and the Breusch-Pagan Lagrange multiplier test for the constructed models. The hypotheses of the study were tested using the STATA program software version 14.

\section{Discussion}

Table 2. Research results

\begin{tabular}{ccccccc}
\hline TOBINQ & Coef. & Robust Std. Err. & $\mathrm{t}$ & $\mathrm{P}>|\mathrm{t}|$ & [ 95\% Conf. & Interval ] \\
\hline STDA & 1.007573 & .0468406 & 21.51 & 0.000 & .915437 & 1.099709 \\
LTDA & .3544023 & .2356071 & 1.50 & 0.133 & -.1090385 & .8178432 \\
TDA & -.0033338 & .0983219 & -0.03 & 0.973 & -.1967337 & .1900662 \\
TDTE & -.0003732 & .0007123 & -0.52 & 0.601 & -.0017743 & .001028 \\
LTDTD & .1444669 & .0833916 & 1.73 & 0.084 & -.0195651 & .3084988 \\
_cons & .6815455 & .0238143 & 28.62 & 0.000 & .6347026 & .7283885 \\
\hline Sigma_u & .64537314 & \multicolumn{5}{c}{ (fraction of variance due to u_i) } \\
Sigma_e & .46443906 & \multicolumn{5}{c}{} \\
rho & .65881021 & \multicolumn{5}{c}{}
\end{tabular}

Table 2 presents the research results. H1 suggests a positive relationship between leverage and firm value. The mixed results provide partial acceptance of the hypothesis. Short-term debt to total assets and long-term debt to total assets proxies showed a significant and positive relationship between leverage and firm value while total debt to total assets and total debt to total equity showed a negative relationship.

The positive association found between short-term debt to total assets and long-term debt to total assets with firm value is in line with the free cash flow theory. Higher leverage can increase firm value because it can alleviate the agency cost of free cash flow through committing to the interest payment and avoid overinvestment (Cheng \& Tzeng, 2011). According to Rashid et al. (2013), this is because debt is an external fund, thus a higher use of debt will increase external monitoring. 
On the contrary, leverage can also decrease firm value. This study discovered that total debt to total assets has a negative association with firm value, supporting the trade-off order theory. This proves that although there are benefits of debts, there is also the cost of debts. The cost of debt financing arises from the increase in the probability of bankruptcy as debt financing subjects a firm to fixed periodic interest and principal payments. The trade-off theory states that the tax benefits associated with leverage are offset by the agency cost of the debt and the cost of financial distress when firms are heavily in debt. The results are similar to the findings of Daud, Norwani, Mansor, and Endut (2016) and Tan and Hamid (2016) who agree that total debt to total asset and firm performance share a negative and significant relationship. Firms with too many unmanageable debts are at high risk of bankruptcy, thus decreasing their firm value. However, these findings are inconsistent with the findings of Mohamad and Saad (2010) who found a significant positive relationship between total debt to total assets and firm value. Even though the research is conducted among listed companies on Bursa Malaysia, the results differ because the research by Mohamad and Saad (2010) covers 5 years and on randomly selected 172 public listed firms on Bursa Malaysia. This research suggests that the trade-off theory is applicable to Malaysian public listed firms and that highly leveraged firms should manage their debts well as it will decrease the firm value.

This research has also shown that total debt to total equity to be insignificant and negatively related to Tobin's Q, similar to Zeitun and Tian (2007) in their panel data research of Jordanian companies. The result implies that firm value will not be affected directly by the ratio of how much the debt holders finance the firm as compared to its owners. However, the finding is in contrast to the findings of Malik et al. (2016) who found that total debt to total equity is positively related to the firm value with no significance. Tan and Hamid (2016) found a different result in their research on the Malaysian plantation sector which found that total debt to total equity significantly affect firm value but in a different direction for two different proxies. Using ROA and ROE for firm value, they found that while TDTE affects ROE positively, it affects ROA negatively. With a different finding, the research conducted on public listed firms in Bursa Malaysia revealed that the changes in firm value do not depend on the total debt to total equity ratio of the firm.

As for debt maturity, $\mathrm{H} 2$ was rejected as this research found that debt maturity has a positive relationship to firm value but is insignificant. The proxy of long-term debt to total debt is not directly related to firm value. In other words, firm value does not depend on the length of debt maturity. Longer maturity is believed to be an advantage as it protects the borrower against interest rate fluctuations. Like in the study of Jiraporn and Tong (2008), they pointed out that a reduction in the proportion of long-term debt is associated with an increase in firm value. Meanwhile, shorter debt maturity could increase firms' value as it can prevent the company from underinvestment. When firms have much outstanding debt, they may forgo the new profitable investment opportunities that require additional debts, thus leading them to have underinvestment. Nevertheless, the firm value of Malaysian public listed firms does not depend directly on debt maturity.

\section{Conclusion}

The research found mixed results on the relationship between capital structure and firm value. Short-term debt to total assets and long-term debt to total assets proxies showed a significant and positive relationship between leverage and firm value, which gives support to the free cash flow theory. Total debt to total assets and total debt to total equity showed a negative association with firm value, supporting the trade-off order theory. This proves that although there are benefits of debts, there are also the costs of debts to be considered. The cost of debt financing arises from the increase in the probability of bankruptcy as debt financing subjects a firm to fixed periodic interest and principal payments. Total debt to total equity is revealed to be insignificant and negatively related to Tobin's Q, implying that debt maturity does not affect firm value directly.

\section{References}

Abor, J. (2005). The effect of capital structure on profitability: An empirical analysis of listed firms in Ghana. The Journal of Risk Finance, 6(5), 438-445. https://doi.org/10.1108/15265940510633505

Abor, J., \& Bokpin, G. A. (2010). Investment opportunities, corporate finance, and dividend payout policy. Studies in Economics and Finance, 27(3), 180-194. https://doi.org/10.1108/10867371011060018

Ahmad, N., \& Aris, Y. B. W. (2015). Does age of the firm determine capital structure decision? Evidence from Malaysian trading and service sector. International Business Management, 9(3), 200-207. https://doi.org/10.3923/ibm.2015.200.207

Alves, P., \& Francisco, P. (2015). The impact of institutional environment on the capital structure of firms during recent financial crises. The Quarterly Review of Economics and Finance, 57, 129-146. https://doi.org/10.1016/j.qref.2014.12.001 
Antoniou, A., Guney, Y., \& Paudyal, K. (2006). The Determinants of Debt Maturity Structure : Evidence from France, Germany and UK. European Financial Management, 12(2), 161-194. https://doi.org/10.1111/j.1354-7798.2006.00315.x

Ardestani, H. S., Rasid, S. Z. A., Basiruddin, R., \& Mehri, M. (2013). Dividend Payout Policy, Investment Opportunity Set and Corporate Financing in the Industrial Products Sector of. Journal of Applied Finance \& Banking, 3(1), 123-136.

Asif, A., \& Aziz, B. (2016). Impact of Capital Structure on Firm Value Creation-Evidence from the Cement Sector of Pakistan. International Journal of Research in Finance and Marketing, 6(6), 231-245.

Awan, H. M., Bhatti, M. I., Ali, R., \& Qureshi, A. (2010). How growth opportunities are related to corporate leverage decisions? Investment Management and Financial Innovations, 7(1), 90-97.

Ayturk, Y., Gurbuz, A. O., \& Yanik, S. (2016). Corporate derivatives use and firm value: Evidence from Turkey. Borsa Istanbul Review, 16(2), 108-120. https://doi.org/10.1016/j.bir.2016.02.001

Berlin, M. (2006). Debt Maturity: What Do Economists Say? What Do CFOs Say? Business Review, (Q1), 3-10. Retrieved from http://www.philadelphiafed.org

Bevan, A. A., \& Danbolt, J. (2002). Capital structure and its determinants in the UK-a decompositional analysis. Applied Financial Economics, 12(3), 159-170. https://doi.org/10.1080/09603100110090073

Chen, J. J. (2004). Determinants of capital structure of Chinese-listed companies. Journal of Business Research, 57, 1341-1351. https://doi.org/10.1016/S0148-2963(03)00070-5

Chen, J., Jiang, C., \& Lin, Y. (2014). What determine firms' capital structure in China? Managerial Finance, 40(10), 1024-1039. https://doi.org/10.1108/MF-06-2013-0163

Cheng, M. C., \& Tzeng, Z. C. (2011). The Effect of Leverage on Firm Value and How The Firm Financial Quality Influence on This Effect. World Journal of Management, 3(2), 30-53.

Dang, V. A. (2011). Leverage, debt maturity and firm investment: An empirical analysis. Journal of Business Finance and Accounting, 38(1-2), 225-258. https://doi.org/10.1111/j.1468-5957.2010.02215.x

Daud, W. M. N. W., Norwani, N. M., Mansor, A. A., \& Endut, W. A. (2016). Does financing decision influence corporate performance in Malaysia? International Journal of Economics and Financial Issues, 6(3), $1165-1171$.

Dawar, V. (2014). Agency theory, capital structure and firm performance: Some Indian evidence. Managerial Finance, 40(12), 1190-1206. https://doi.org/10.1108/MF-10-2013-0275

Dhrymes, P. J., \& Kurz, M. (1967). Investment, Dividend, and External Finance Behavior of Firms. Determinants of Investment Behavior, 427-485.

Ebaid, I. E. S. (2009). The impact of capital-structure choice on firm performance: Empirical evidence from Egypt. The Journal of Risk Finance, 10(5), 477-487. https://doi.org/10.1108/15265940911001385

Eldomiaty, T. I. (2008). Determinants of corporate capital structure: Evidence from an emerging economy. International Journal of Commerce and Management, 17(1/2), 25-43. https://doi.org/10.1108/10569210710774730

Elkelish, W. W., \& Marshall, A. P. (2012). Financial Structure and Firm Value: Empirical Evidence from the Emerging Market of the United Arab Emirates. International Journal of Business Research, 7(1).

Fama, E. F. (1974). The Empirical Relationships between the Dividend and Investment Decisions of Firms. The American Economic Review, 64(3), 304-318.

Fan, J. P. H., Titman, S., \& Twite, G. (2012). An international comparison of capital structure and debt maturity choices. Journal of Financial and Quantitative Analysis, 47(1), 23-56. https://doi.org/10.1017/S0022109011000597

Fosu, S. (2013). Capital structure, product market competition and firm performance: Evidence from South Africa. Quarterly Review of Economics and Finance, 53, 140-151. https://doi.org/10.1016/j.qref.2013.02.004

Handoo, A., \& Sharma, K. (2014). A study on determinants of capital structure in India. IIMB Management Review, 26(3), 170-182. http://doi.org/10.1016/j.iimb.2014.07.009

Hermuningsih, S. (2013). Profitability, Growth Opportunity, Capital Structure and the Firm Value. Bulletin of 
Monetary, Economics and Banking, 115-136.

Javeed, A., Hassan, M., \& Azeem, M. (2014). Interrelationship among Capital Structure, Corporate Governance Measures and Firm Value: Panel Study from Pakistan. Pakistan Journal of Commerce and Social Sciences, $8(3), 572-589$.

Jiraporn, P., \& Liu, Y. (2008). Capital Structure, Staggered Boards, and Firm Value. Financial Analysts Journal, 64(1), 49-60. https://doi.org/10.2469/faj.v64.n1.7

Jiraporn, P., \& Tong, S. (2008). Debt Maturity Structure, Agency Costs, And Firm Value: Evidence From 1973-2004.

Karim, Z. A. (2012). Monetary policy effects on investment spending: a firm-level study of Malaysia. Studies in Economics and Finance, 29, 268-286. https://doi.org/10.1108/10867371211266919

Karim, Z. A., \& Azman-Saini, W. N. W. (2013). Firm-level investment and monetary policy in Malaysia: Do the interest rate and broad credit channels matter? Journal of the Asia Pacific Economy, 18(3), 396-412. https://doi.org/10.1080/13547860.2012.742686

Khaw, K. L. H., \& Lee, B. C. J. (2016). Debt Maturity, Underinvestment Problem and Corporate Value. Asian Academy of Management Journal of Accounting and Finance, 12(Suppl. 1), 1-17. https://doi.org/10.21315/aamjaf2016.12.S1.1

Kodongo, O., Mokoaleli-Mokoteli, T., \& Maina, L. N. (2015). Capital Structure, Profitability And Firm Value: Panel Evidence Of Listed Firms In Kenya. The African Finance Journal, 17(1), 1-20. https://doi.org/10.2139/ssrn.2465422

Loncan, T. R., \& Caldeira, J. F. (2014). Capital Structure, Cash Holdings and Firm Value : a Study of Brazilian $\begin{array}{lllll}\text { Listed Firms. Revista Contabilidade \& } & \text { Finanças, 25(64), }\end{array}$ https://doi.org/10.1590/S1519-70772014000100005

Malik, M. S., Awais, M., \& Qaisar, A. (2016). Capital Structure Payoff : An Analysis of the Non- Financial Sectors of Pakistan. European Academic Research, 3(12), 13140-13165.

Mohamad, N. E. A. B., \& Saad, N. B. M. (2010). Working Capital Management : The Effect of Market Valuation and Profitability in Malaysia. International Journal of Business and Management, 5(11), 140-147. https://doi.org/10.5539/ijbm.v5n11p140

Myers, S. C. (1977). Determinants of corporate borrowing. Journal of Financial Economics, 5(2), 147-175. https://doi.org/10.1016/0304-405X(77)90015-0

Nimalathasan, B., \& Brabete, V. (2010). Capital Structure And Its Impact On Profitability: A Study Of Listed Manufacturing Companies In Sri Lanka. Young Economists Journal/Revista Tinerilor Economisti, 8(15), 7-16.

Nor, F. M., Ibrahim, K., Haron, R., Ibrahim, I., \& Alias, M. A. (2012). Practices of Capital Structure Decisions: Malaysia Survey Evidence. International Review of Business Research Papers, 8(1), 33-63.

Orman, C., \& Köksal, B. (2017). Debt Maturity across Firm Types: Evidence from a Major Developing Economy. Emerging Markets Review, 30, 169-199. https://doi.org/10.1016/j.ememar.2016.12.001

Pike, R., \& Neale, B. (2009). Corporate finance and investment: decisions and strategies (6th ed.). Pearson Education.

Rahim, R. A., Yaacob, M. H., Alias, N., \& Nor, F. M. (2010). Investment, Board Governance and Firm Value : A Panel Data Analysis. International Review of Business Research Papers, 6(5), 293-302.

Ramadan, Z. S., \& Ramadan, I. Z. (2015). Capital Structure and Firm's Performance of Jordanian Manufacturing Sector. International Journal of Economics and Finance, 7(6), 279-284. https://doi.org/10.5539/ijef.v7n6p279

Rashid, M., Nor, F. M., \& Ibrahim, I. (2013). Evidence of dividend catering theory in Malaysia: Implications for investor sentiment. Contemporary Economics, 7(4), 99-110. https://doi.org/10.5709/ce.1897-9254.125

Salim, M., \& Yadav, R. (2012). Capital Structure and Firm Performance: Evidence from Malaysian Listed Companies. Procedia - Social and Behavioral Sciences, 65(ICIBSoS), 156-166. https://doi.org/10.1016/j.sbspro.2012.11.105

Sheikh, N. A., \& Wang, Z. (2013). The impact of capital structure on performance. International Journal of Commerce and Management, 23(4), 354-368. https://doi.org/10.1108/IJCoMA-11-2011-0034 
Simmons-Süer, B. (2016). Cost of capital and US investment: Does financing matter after all? Quarterly Review of Economics and Finance, 60, 86-93. https://doi.org/10.1016/j.qref.2015.11.008

Stiglitz, J. E. (1974). On the irrelevance of corporate financial policy. American Economic Review, 64(6), 851-866.

Stulz, R. M. (1990). Managerial discretion and optimal financing policies. Journal of Financial Economics, 26, 3-27. https://doi.org/10.1016/0304-405X(90)90011-N

Tahir, I. M., \& Razali, A. R. (2011). the Relationship Between Enterprise Risk Management (Erm) and Firm Value: Evidence From Malaysian Public Listed Companies. International Journal of Economics and Management Sciences, 1(2), 32-41.

Tan, S. L., \& Hamid, N. I. N. A. (2016). Capital Structure and Performance of Malaysia Plantation Sector. Journal of Advanced Research in Social and Behavioural Sciences, 3(1), 34-45.

Tang, C. H. (Hugo), \& Jang, S. (Shawn). (2007). Revisit to the determinants of capital structure: A comparison between lodging firms and software firms. International Journal of Hospitality Management, 26(1), 175-187. https://doi.org/10.1016/j.ijhm.2005.08.002

Terra, P. R. S. (2009). Are leverage and debt maturity complements or substitutes? Evidence from Latin America. $\begin{array}{lllll}\text { RAM. Revista de Administração } & \text { Mackenzie, } & \text { 10(6), }\end{array}$ https://doi.org/10.1590/S1678-69712009000600003

Twairesh, A. E. M. (2014). The Impact of Capital Structure on Firm's Performance Evidence from Saudi Arabia. Journal of Applied Finance \& Banking, 4(2), 183-193.

Vătavu, S. (2015). The Impact of Capital Structure on Financial Performance in Romanian Listed Companies. Procedia Economics and Finance, 32(15), 1314-1322. https://doi.org/10.1016/S2212-5671(15)01508-7

Vo, X. V., \& Ellis, C. (2016). An empirical investigation of capital structure and firm value in Vietnam. Finance Research Letters. https://doi.org/10.1016/j.frl.2016.10.014

Wang, T. (2015). Capital Structure, Debt Tax Shield, and Firm Value: A Propensity Score Matching Approach. Tufts University.

Ying, L. C., Annie, L., Jia, S. T. L., \& Ngar, T. S. (2012). How Independent Variables Affect Dividend Policy That Will Eventually Change Firm Value. Universiti Tunku Abdul Rahman.

Zeitun, R., \& Tian, G. G. (2007). Capital structure and corporate performance: Evidence from Jordan. Australasian Accounting Business and Finance Journal, 1(4), 40-61.

Zou, H. (2010). Hedging Affecting Firm Value via Financing and Investment: Evidence from Property Insurance Use. Financial Management, 39(3), 965-996. https://doi.org/10.1111/j.1755-053X.2010.01101.x

\section{Copyrights}

Copyright for this article is retained by the author(s), with first publication rights granted to the journal.

This is an open-access article distributed under the terms and conditions of the Creative Commons Attribution license (http://creativecommons.org/licenses/by/4.0/). 